\title{
PENGARUH KARAKTERISTIK PEKERJA SOSIAL, PASANGAN, INTERAKSI SUAMI-ISTRI, DAN KESEJAHTERAAN SUBJEKTIF TERHADAP KUALITAS PERKAWINAN PEKERJA SOSIAL
}

\author{
Octaviniant Aspary ${ }^{1^{*}}$, Herien Puspitawati ${ }^{2}$, Diah Krisnatuti ${ }^{2}$ \\ ${ }^{1}$ Program Studi Magister Ilmu Keluarga dan perkembangan Anak, Sekolah Pascasarjana, \\ IPB University, Bogor 16880, Indonesia \\ ${ }^{2}$ Departemen IImu Keluarga dan Konsumen, Fakultas Ekologi Manusia, \\ IPB University, Bogor 16880, Indonesia
}

*)E-mail: octaviniant_aspary@apps.ipb.ac.id

\begin{abstract}
Abstrak
Jakarta memiliki 28.819 kader PKK sampai tingkat Rukun Tetangga (RT) dan 70.902 kelompok dasawisma sebagai role model keluarga sejahtera bagi masyarakat di sekitarnya. Penelitian ini bertujuan untuk menganalisis pengaruh karakteristik pekerja sosial dan pasangan, interaksi suami-istri, dan kesejahteraan subjektif terhadap kualitas perkawinan pekerja sosial di Provinsi Jakarta. Penelitian ini menggunakan metode kuantitatif. Contoh penelitian ini adalah pekerja sosial yang berprofesi sebagai kader Pemberdayaan dan Kesejahteraan Keluarga (PKK) tingkat kelurahan pada 10 kecamatan di Jakarta Timur. Sebanyak 100 pekerja sosial yang terdiri atas kelompok lama menikah $\leq 10$ tahun dan $>10$ tahun dipilih menggunakan teknik disproportional random sampling. Data dikumpulkan dengan metode self-report dan dianalisis dengan SPSS (Statistical Package for the Social Sciences) dan SmartPLS (partial least squares). Uji t menunjukkan tidak ada perbedaan yang signifikan antara pendapatan keluarga, pendidikan, interaksi suami-istri, kesejahteraan subjektif, dan kualitas perkawinan pada kedua kelompok lama menikah. Rata-rata indeks interaksi suami-istri dan kualitas perkawinan lebih tinggi dari kesejahteraan subyektif. Pendidikan dan pendapatan keluarga berpengaruh secara signifikan terhadap interaksi suami-istri. Kesejahteraan subjektif dan interaksi suami-istri berpengaruh secara signifikan terhadap kualitas perkawinan. Interaksi suami-istri melalui kesejahteraan subjektif berpengaruh secara tidak langsung terhadap kualitas perkawinan. Hasil penelitian menunjukkan tidak terdapat pengaruh lama menikah terhadap kualitas perkawinan.
\end{abstract}

Kata kunci: interaksi suami-istri, kesejahteraan subjektif, kualitas perkawinan, pekerja sosial, PKK

\section{The Characteristic of Social Workers and Spouse, Husband Wife Interaction and Subjective Welfare on Marital Quality of Social Workers}

\begin{abstract}
Jakarta has 28,819 PKK cadres up to the Rukun Tetangga (RT) level and 70,902 dasawisma groups who act as a role model for the prosperous family in the community. This study aimed to analyze the effect of the social workers and spouse characteristic, husband-wife interaction, and subjective welfare on the marital quality of social workers in Jakarta Province. This research used quantitative methods. The sample of this research was social workers who worked as cadres of Family Empowerment and Welfare (Kader PKK) at the village level in 10 sub-districts in East Jakarta. A total of 100 social workers were selected using a disproportional random sampling technique. The sample was divided into 2 groups based on the length of marriage: $\leq 10$ years and $>10$ years. Data were collected using the self-report method and analyzed using SPSS (Statistical Package for the Social Sciences) and SmartPLS (partial least squares). The T-test showed that there was no significant difference between family income, education, husband-wife interaction, subjective welfare, and marital qualitye in the two groups. The average index scores of husband-wife interaction and marital quality were higher than that of subjective welfare. Education and family income had a significant effect on husband-wife interaction. Subjective welfare and husband-wife interactions had a significant effect on the marital quality. Husband-wife interaction had an indirect effect on the marital quality through subjective welfare. The results showed that there was no effect between the length of marriage and the marital quality.
\end{abstract}

Keywords: husband-wife interaction, marital quality, PKK, social worker, subjective welfare

\section{PENDAHULUAN}

Keberhasilan perkawinan sebuah keluarga ditandai dengan interaksi suami-istri yang baik sehingga terbangun sistem yang menjalankan fungsinya dan menjadi keluarga sejahtera (Anderson, 1943). Tinggi rendahnya kualitas perkawinan dapat mencerminkan 
kesejahteraan, kebahagiaan, kepuasan, atau kesuksesan dalam perkawinan. Kualitas perkawinan yang tinggi berkaitan dengan menurunnya tingkat depresi yang dialami oleh seseorang (Williams, 2003) dan peningkatan kualitas kesehatan (Umberson et al., 2006). Sebuah perkawinan cenderung mengalami penurunan kualitas secara bertahap setelah tahun pertama perkawinan, mulai dari 0-5 tahun, 10 tahun, dan 15 tahun, namun jarang ditemukan pada pasangan dengan lama menikah lebih lama dari 24 tahun (Carrere et al., 2000).

Salah satu faktor yang memengaruhi kualitas perkawinan adalah interaksi suami-istri (Dewi, Puspitawati, \& Krisnatuti, 2019). Sementara itu, faktor lain yang berpengaruh adalah kesejahteraan subjektif (Riyanti, Prabowo, \& Puspitawati, 1998). Spanier (1976) membagi kualitas perkawinan menjadi 3 (tiga), yaitu kebahagiaan perkawinan (marital happiness), kepuasan perkawinan (marital satisfaction), dan penyesuaian perkawinan (marital adjustment).

Proses interaksi suami-istri ditandai dengan adanya rasa saling ketergantungan di antara pasangan (DeVellis, Lewis, \& Sterba, 2003). Rasa ini ditandai dengan tingkat love (nurturing) atau tingkat cinta terhadap pasangan; domineering (Hostile-Dominance) atau tingkat dominasi terhadap pasangan; directing (Friendly Dominance); hostility atau keharmonisan komunikasi antar pasangan; submissive (Hostile-Submission) atau cara mengungkapkan emosi terhadap pasangan, dan respect atau perilaku saling menghargai antar pasangan (Chuang, 2005). Suami ataupun istri yang merasa dihargai, bernilai, dan diperhatikan mencerminkan interaksi suami-istri yang ideal (Anderson \& Sabatelli, 2011). Bradbury, Fincham, dan Beach (2000) menemukan bahwa komunikasi antar pasangan dan kesamaan kepribadian menjadi salah satu faktor yang menentukan kepuasan perkawinan.

Riyanti et al. (1998) mengungkapkan peranan penting dalam kualitas sebuah perkawinan ditentukan oleh kesejahteraan subjektif atau yang dikenal dengan Family Subjective Quality of Life (SQL) yang menunjukkan kepuasan pribadi dan keluarga serta rasa syukurnya terhadap kehidupan keluarga. Menurut Iskandar (2012), kesejahteraan rumah tangga dipengaruhi beberapa faktor, yaitu tingkat pendidikan, usia, pekerjaan, ukuran rumah tangga, status perkawinan, siklus hidup, dan tempat tinggal. Penelitian Anindya dan Soetjiningsih (2017) juga memperkuat adanya hubungan positif antara kesejahteraan subjektif individu dengan tingkat kepuasan perkawinan.

Pekerja sosial adalah agent of change bagi kesejahteraan masyarakat di sekitarnya sehingga perlu didukung dengan kondisi keluarga yang kuat dan stabil. Wilson (2004) mengatakan bahwa seseorang yang bekerja pada organisasi sosial memiliki dampak terhadap kesehatan dan kesejaheraan kehidupannya. Salah satu profesi pekerja sosial di Indonesia adalah sebagai kader atau pengurus kelompok Pemberdayaan dan Kesejahteraan Keluarga (PKK). Presiden Joko Widodo dalam pidato Hari Kesatuan Gerak PKK Ke-45 pada tahun 2017 menyatakan bahwa PKK harus terus membangun dan memperkuat keluarga-keluarga di Indonesia (megapolitan.antaranews.com, 2017). PKK juga diharapkan bisa menjadi pengarah dalam mengajak, merangkul, dan menggerakkan masyarakat khususnya ibu sebagai upaya untuk membentuk sumber daya manusia unggul.

Selanjutnya, DKI Jakarta memiliki pekerja sosial PKK terbanyak sehingga menjadikan PKK sebagai mitra strategis pemerintah melalui Instruksi Gubernur Nomor 2 Tahun 2019 tentang Sinkronisasi dan Integrasi Pelayanan Kesejahteraan Keluarga Satu Pintu melalui TP PKK Provinsi DKI Jakarta yang artinya hasil pendataan PKK akan dijadikan rujukan untuk tiga Satuan Kerja Perangkat Daerah (SKPD), antara lain Dinas Pemberdayaan Perlindungan Anak dan Pengendalian Penduduk (DPPAPP), Dinas Ketahanan Pangan, Kelautan dan Pertanian (DKPKP), dan Dinas Kesehatan (DINKES) di DKI Jakarta. Menjadi pekerja sosial di Jakarta menjadi tantangan besar karena rasio gini naik sebesar 0,004 poin yang menunjukkan bahwa terjadi kenaikan ketimpangan sosial (BPS, 2019) dan 118 dari 264 kelurahan masih tergolong wilayah kumuh (Kementerian Agraria dan Tata Ruang/Badan Pertanahan Nasional, 2019).

Penelitian yang berkaitan dengan pekerja sosial umumnya berfokus pada peningkatan kapasitas pekerja sosial untuk membantu kesuksesan program tertentu, namun belum ada penelitian yang fokus pada kondisi internal keluarga atau kualitas perkawinan keluarga pekerja sosial itu sendiri. Penelitian Komariah, Prijana, dan Winoto (2018) menemukan bahwa pengurus PKK memiliki pengetahuan tentang kesehatan khususnya kesehatan lingkungan dan menyadari dampaknya terhadap keluarga. Sementara itu, penelitian Syam et al. (2015) menitikberatkan pada pengurus PKK yang 
belum memiliki pengetahuan memadai mengenai komunikasi pengasuhan. Kebaruan dari penelitian ini adalah meneliti kondisi internal keluarga pekerja sosial yang dilihat dari kualitas perkawinannya. Atas dasar penjelasan tersebut, penelitian ini bertujuan untuk: 1) mengidentifikasi karakteristik pekerja sosial dan pasangan, interaksi suami-istri, kesejahteraan subjektif, dan kualitas perkawinan pada pekerja sosial usia perkawinan $\leq 10$ tahun dan $>10$ tahun, dan 2) menganalisis pengaruh interaksi suami-istri dan kesejahteraan subjektif terhadap kualitas perkawinan.

\section{METODE}

Penelitian ini menggunakan pendekatan struktural fungsional dengan desain kuantitatif. Penelitian dilakukan pada Januari-Februari 2020 dengan mengambil lokasi di DKI Jakarta tepatnya di Kota Administrasi Jakarta Timur yang dipilih secara purposif dengan pertimbangan memiliki kelurahan terbanyak dan jumlah kelompok pekerja sosial terbanyak pula berdasarkan Peraturan Gubernur DKI Jakarta Nomor 958 Tahun 2018. Populasi pada penelitian ini adalah pekerja sosial TP PKK di tingkat kelurahan yang berperan dalam pengawasan dan pelaksanaan kegiatan di lapangan.

Dari Kota Administrasi Jakarta Timur, dipilih secara purposif 10 kelurahan, kemudian dari setiap kelurahan terpilih dikumpulkan data untuk kerangka contoh berupa jumlah pengurus yang telah menikah selama $\leq 10$ tahun dan $>10$ tahun dengan karakteristik keluarga utuh dengan atau tanpa anak. Dari kerangka contoh yang sudah dibuat, dipilih masing-masing 50 orang secara disproporsional random sampling berdasarkan kelompok lama menikah sehingga secara total penelitian ini melibatkan 100 responden.

Interaksi suami-istri adalah derajat hubungan antara suami-istri yang diukur menggunakan alat ukur yang dikembangkan oleh Chuang (2005). Jumlah butir pertanyaan dikembangkan dari 6 dimensi (love/derajat cinta, directing/sikap dominasi, note domineering/sikap emosi, note hostility/keharmonisan komunikasi, note submissive/sikap saling menuruti, dan respect/saling menghargai) dengan total pertanyaan 24 butir. Kuesioner menggunakan skala Likert (1-4), yaitu 1=tidak pernah; $2=$ =jarang; $3=$ =sering; $4=$ selalu. Uji validitas dan reliabilitas pada kuesioner ini menunjukkan nilai Cronbach's alpha 0,820.
Kesejahteraan subjektif adalah kepuasan terhadap tingkat pemenuhan kebutuhan dasar dan perkembangan kehidupan keluarga yang mengacu pada perasaan puas yang dirasakan oleh pekerja sosial. Variabel ini diukur menggunakan kuesioner dari Herawati dan Puspitawati (2012) yang terdiri atas tiga dimensi yaitu kesejahteraan fisik, psikologi, dan sosial. Kuesioner diukur menggunakan skala pilihan tidak puas (skor), kurang puas (skor), dan puas (skor). Kesejahteraan subjektif ini dikategorikan menjadi rendah, sedang, dan tinggi. Telah dilakukan uji validitas dan reliabilitas pada 25 butir pertanyaan $(\alpha=0,875)$.

Kualitas perkawinan adalah ukuran berdasarkan kebahagiaan, kepuasan, dan penyesuaian antara suami dan istri dalam menjalani rumah tangga. Pengukuran merujuk pada alat ukur yang digunakan oleh penelitian sebelumnya (Canel, 2013) yang terbagi menjadi tiga dimensi yaitu kebahagiaan perkawinan (marital happiness), kepuasan perkawinan (marital satisfaction), dan penyesuaian perkawinan (marital adjustment). Jumlah item yang digunakan pada penelitian ini adalah 25 pertanyaan dengan pilihan jawaban tidak puas (skor), kurang puas (skor), dan puas (skor). Telah dilakukan uji validitas dan reliabilitas pada 25 butir pertanyaan $(\alpha=0,958)$.

Data kemudian melalui proses editing, coding, scoring, entry, cleaning, dan analisis data. Nilai skor keempat variabel penelitian ditransformasikan dalam bentuk indeks dengan cut off rendah $(<60)$, sedang $(60-80)$, dan tinggi (>80) (Wanyama, 2017). Pengolahan dan analisis data menggunakan program Microsoft Excel, Statistical Package for Social Science (SPSS), dan SEM Smart PLS. Uji yang dilakukan antara lain uji $\mathrm{t}$ dan uji hubungan Structural Equation Modeling (SEM).

\section{HASIL}

\section{Karakteristik Keluarga}

Pada data demografis ditemukan bahwa profesi yang banyak digeluti oleh hampir seluruh (92\%) pekerja sosial adalah ibu rumah tangga. Pada kedua kelompok pekerja sosial dan pasangan, lebih dari 50 persen tamat SMA. Rata-rata usia pekerja sosial pada kelompok lama menikah $\leq 10$ tahun adalah 30,68 tahun dengan lama bergabung di PKK rata-rata 1,58 tahun. Sementara itu, pada kelompok lama menikah $>10$ tahun rata-rata usia pekerja sosial adalah 47,94 tahun dengan lama gabung rata-rata adalah 9,52 tahun. 
Tabel 1 Karakteristik pekerja sosial dan pasangan berdasarkan data demografi dan aktivitas sosial

\begin{tabular}{|c|c|c|c|c|}
\hline Karakteristik & $\begin{array}{c}\text { Satua } \\
n\end{array}$ & $\begin{array}{c}\text { Lama } \\
\text { menikah } \\
\leq 10 \text { th } \\
\end{array}$ & $\begin{array}{c}\text { Lama } \\
\text { menikah } \\
>10 \text { th }\end{array}$ & $\begin{array}{c}\mathrm{p}- \\
\text { value }\end{array}$ \\
\hline \\
\hline Usia & tahun & 30,68 & 47,94 & $\underset{* *}{0,000}$ \\
\hline $\begin{array}{l}\text { Lama } \\
\text { gabung }\end{array}$ & tahun & 1,58 & 9,52 & $\underset{* *}{0,000}$ \\
\hline $\begin{array}{l}\text { Lama } \\
\text { pendidikan }\end{array}$ & tahun & 12 & 12 & 0,272 \\
\hline \multicolumn{5}{|l|}{ Pasangan } \\
\hline Usia & tahun & 34,72 & 52,34 & $\underset{* *}{0,000}$ \\
\hline $\begin{array}{l}\text { Lama } \\
\text { pendidikan }\end{array}$ & tahun & 12 & 12 & 0,426 \\
\hline $\begin{array}{l}\text { Pendapatan } \\
\text { keluarga/bul }\end{array}$ & $\mathrm{Rp}$ & $\begin{array}{c}8.772 .3 \\
33\end{array}$ & $\begin{array}{c}6.048 .3 \\
63\end{array}$ & 0,346 \\
\hline
\end{tabular}

Keterangan: **nyata pada $\mathrm{p} \leq 0,01 ;{ }^{*}$ nyata pada $\mathrm{p} \leq 0,05$ $(\mathrm{n}=50) ;$ Pendapatan/bulan $>$ Rp6.000.000=Sangat Tinggi (BPS, 2019)

Rata-rata usia pasangan pada kelompok lama menikah $\leq 10$ tahun adalah 34,72 tahun dan pada kelompok lama menikah $>10$ tahun adalah 52,34 tahun. Rata-rata pendapatan keluarga per bulan kelompok lama menikah $\leq 10$ tahun adalah Rp8.772.333 dan kelompok lama menikah $>10$ tahun Rp6.048.363. Tidak terdapat perbedaan signifikan antara lama pendidikan pekerja sosial dan pasangan serta pendapatan kedua kelompok pekerja sosial berdasarkan lama menikah (Tabel 1)

\section{Interaksi Suami-Istri}

Hasil penelitian mengungkapkan, 6 dari 10 pekerja sosial pada kelompok lama menikah $\leq 10$ tahun berada pada interaksi suami-istri kategori sedang, sedangkan lebih dari setengah (54\%) pekerja sosial kelompok lama menikah $>10$ tahun berada pada kategori tinggi. Rata-rata indeks interaksi suami-istri pekerja sosial kelompok lama menikah $\leq 10$ tahun adalah 80,4 dan rata-rata interaksi suami-istri yang diperoleh pekerja sosial kelompok lama menikah $>10$ tahun adalah 80,6 . Hal ini juga menunjukkan bahwa hubungan timbal balik pada kelompok lama menikah $>10$ tahun lebih baik dibandingkan dengan kelompok lama menikah $\leq 10$ tahun walaupun hasil uji beda tidak menunjukkan perbedaan signifikan pada variabel interaksi suami istri (Tabel 2).

Love (Nurturing). Hasil kajian memperlihatkan lebih dari setengah para pekerja sosial dengan lama menikah $\leq 10$ tahun $(68 \%)$ dan lama menikah >10 tahun (66\%) memiliki love (nurturing) terkategori tinggi. Hal ini mengindikasikan bahwa kedua kelompok pekerja sosial dapat menunjukkan rasa cintanya dengan baik dan akan menyebabkan semakin tinggi interaksi suami-istri yang mendorong tingginya kualitas perkawinan.

Directing (Friendly Dominance). Hasil kajian menunjukkan lebih dari setengah pekerja sosial lama menikah $\leq 10$ tahun $(54 \%)$ dan pekerja sosial lama menikah $>10$ tahun $(60 \%)$ memiliki directing (friendly dominance) terkategori tinggi. Hal ini mengindikasikan bahwa pekerja sosial dapat menyampaikan sesuatu yang diharapkan dengan cukup baik kepada pasangan dan akan menyebabkan semakin tinggi interaksi suamiistri yang mendorong tingginya kualitas perkawinan.

Respect (Friendly Submissive). Lebih dari setengah pekerja sosial dengan lama menikah $\leq 10$ tahun $(62 \%)$ dan $>10$ tahun $(70 \%)$ memiliki respect (friendly submissive) yang berada pada kategori tinggi. Hal ini memberikan indikasi bahwa pekerja sosial dan pasangan memiliki hubungan yang saling menghormati satu sama lain dan akan menyebabkan semakin tinggi interaksi suami-istri yang mendorong tingginya kualitas perkawinan.

Note Domineering (Hostile-Dominance). Hasil kajian memperlihatkan bahwa lebih dari setengah pekerja sosial lama menikah $\leq 10$ tahun $(54 \%)$ dan pekerja sosial lama menikah $>10$ tahun (56\%) memiliki note domineering (hostile dominance) terkategori sedang. Hal ini mengindikasikan bahwa sikap terbuka terhadap emosi yang dirasakan terhadap pasangan tergolong cukup baik.

Note Hostility. Hasil kajian memperlihatkan 70 persen pekerja sosial lama menikah $\leq 10$ tahun dan 74 persen pekerja sosial lama menikah $>10$ tahun memiliki note hostility terkategori tinggi. Hal ini mengindikasikan bahwa keharmonisan komunikasi antara pekerja sosial dan pasangan tergolong baik dan akan menyebabkan semakin tinggi interaksi suami-istri yang mendorong tingginya kualitas perkawinan.

Note Submissive (Hostile-Submission). Hasil kajian menunjukkan lebih dari setengah pekerja sosial dengan lama menikah $\leq 10$ tahun $(62 \%)$ dan $>10$ tahun (54\%) memiliki note submissive terkategori sedang. Hal ini mengindikasikan bahwa sikap saling menuruti keinginan antara pekerja sosial dan pasangan berada pada kategori cukup baik. 
Tabel 2 Sebaran pekerja sosial berdasarkan kategori indeks variabel interaksi suami-istri dan lama menikah

\begin{tabular}{|c|c|c|c|c|c|c|c|c|c|}
\hline \multirow{3}{*}{ Dimensi } & \multicolumn{4}{|c|}{ Lama menikah $\leq 10$ th } & \multicolumn{4}{|c|}{ Lama menikah $>10$ th } & \multirow{3}{*}{$\begin{array}{c}\mathrm{p}- \\
\text { value }\end{array}$} \\
\hline & $\begin{array}{c}\text { Rendah } \\
(<60)\end{array}$ & $\begin{array}{l}\text { Sedang } \\
(60-80)\end{array}$ & $\begin{array}{l}\text { Tinggi } \\
(>80)\end{array}$ & $\begin{array}{c}\text { Rataan } \\
\pm \text { Std }\end{array}$ & $\begin{array}{l}\text { Rendah } \\
\qquad(<60)\end{array}$ & $\begin{array}{l}\text { Sedang } \\
(60-80)\end{array}$ & $\begin{array}{l}\text { Tinggi } \\
(>80)\end{array}$ & $\begin{array}{c}\text { Rataan } \\
\pm \text { Std }\end{array}$ & \\
\hline & $\%$ & $\%$ & $\%$ & & $\%$ & $\%$ & $\%$ & & \\
\hline$\overline{L N}$ & 2 & 30 & 68 & $89,4 \pm 11,3$ & 2 & 32 & 66 & $85,9 \pm 13,8$ & 0,160 \\
\hline FD & 8 & 38 & 54 & $78,0 \pm 12,3$ & 6 & 34 & 60 & $79,1 \pm 11,0$ & 0,650 \\
\hline FS & 0 & 38 & 62 & $87,2 \pm 10,7$ & 4 & 26 & 70 & $86,4 \pm 13,7$ & 0,750 \\
\hline $\mathrm{NHD}$ & 6 & 54 & 40 & $63,2 \pm 11,3$ & 4 & 56 & 40 & $64,0 \pm 11,5$ & 0,710 \\
\hline NHT & 0 & 30 & 70 & $89,7 \pm 10,6$ & 0 & 26 & 74 & $90,5 \pm 10,6$ & 0,710 \\
\hline NHS & 12 & 62 & 26 & $72,4 \pm 14,6$ & 8 & 54 & 38 & $75,9 \pm 14,3$ & 0,240 \\
\hline Total INT & 0 & 60 & 40 & $8,4 \pm 4,9$ & 0 & 46 & 54 & $80,6 \pm 6,0$ & 0,808 \\
\hline
\end{tabular}

Keterangan: \% = persentase sebaran pekerja sosial lama nikah $\leq 10$ tahun dan $>10$ tahun $(n=50),{ }^{* *}$ nyata pada $p \leq 0,01 ;{ }^{*}$ nyata pada $p \leq 0,05$. INT=interaksi suami-istri, $\mathrm{LN}=$ love (nurturing), $\mathrm{FD}=$ directing (friendly dominance), $\mathrm{FS}=$ respect (friendly submission), $\mathrm{NHD}=$ note domineering (hostile dominance), $\mathrm{NHT}=$ note hostility, $\mathrm{NHS}=$ note submissive (hostile submission)

\section{Kesejahteraan Subjektif}

Hasil penelitian menunjukkan bahwa kesejahteraan subjektif pada lebih dari setengah (56\%) pekerja sosial kelompok lama nikah $\leq 10$ tahun dan lebih dari setengah (54\%) pekerja sosial kelompok lama menikah $>10$ tahun sama-sama berada pada kategori kesejahteraan subjektif sedang. Hal ini disebabkan karena kesejahteraan fisik, psikologis, dan sosial berada pada kategori sedang dan perlu ditingkatkan. Rata-rata indeks kesejahteraan subjektif pada kelompok lama menikah $\leq 10$ tahun adalah 68,9 dan pada kelompok lama menikah $>10$ tahun adalah 72,1 . Tidak terdapat perbedaan signifikan pada variabel kesejahteraan subjektif berdasarkan lama menikah pada hasil uji beda (Tabel 3).

Kesejahteraan Fisik. Hasil kajian menunjukkan bahwa sebanyak 46 persen pada masing-masing kelompok pekerja sosial lama menikah $\leq 10$ tahun dan $>10$ tahun memiliki kesejahteraan fisik terkategori sedang dengan nilai rata-rata berturut-turut 61,1 dan 63,3 . Hal tersebut mengindikasikan bahwa pekerja sosial masih harus meningkatkan partisipasi dalam kegiatan-kegiatan yang mendorong keterlibatan pada aktivitas-aktivitas sosial.

Kesejahteraan Psikologis. Hasil kajian menunjukkan bahwa sebanyak 40 persen pekerja sosial lama menikah $\leq 10$ tahun dan 46 persen pekerja sosial lama menikah $>10$ tahun memiliki kesejahteraan psikologis terkategori tinggi dengan nilai rata-rata berturut-turut 75,6 dan 79,3. Hal ini mengindikasikan pekerja sosial masih harus meningkatkan aktivitasaktivitas sosial guna meningkatkan rasa syukur terhadap pencapaian hidup dan lebih optimis memandang masa depan.

Kesejahteraan Sosial. Hasil kajian menunjukkan bahwa sebanyak 54 persen pekerja sosial lama menikah $\leq 10$ tahun dan 40 persen pekerja sosial lama menikah $>10$ tahun memiliki kesejahteraan sosial terkategori sedang dengan nilai rata-rata berturut-turut 71,2 dan 75,3 . Hal ini mengindikasikan bahwa pekerja sosial masih harus meningkatkan partisipasi sosial di luar rumah.

\section{Kualitas Perkawinan}

Kualitas perkawinan pada lebih dari setengah (54\%) pekerja sosial kelompok lama menikah $\leq 10$ tahun dan lebih dari setengah $(60 \%)$ pekerja sosial kelompok lama menikah $>10$ tahun sama-sama berada pada kategori tinggi. Dari ketiga dimensi pada variabel kualitas perkawinan, marital adjustment menunjukkan rata-rata indeks paling rendah dibandingkan dengan marital happiness dan marital satisfaction pada kedua kelompok lama menikah. Rata-rata indeks kualitas perkawinan yang diperoleh pekerja sosial kelompok lama menikah $\leq 10$ tahun adalah 81,5 dan rata-rata indeks kualitas perkawinan yang diperoleh pekerja sosial kelompok lama menikah $>10$ tahun adalah 83,9. 
Tabel 3 Sebaran pekerja sosial berdasarkan kategori indeks variabel kesejahteraan subjektif dan lama menikah

\begin{tabular}{|c|c|c|c|c|c|c|c|c|c|}
\hline \multirow{3}{*}{ Dimensi } & \multicolumn{4}{|c|}{ Lama menikah $\leq 10$ th } & \multicolumn{4}{|c|}{ Lama menikah $>10$ th } & \multirow{3}{*}{$\begin{array}{c}\mathrm{P}- \\
\text { value }\end{array}$} \\
\hline & $\begin{array}{l}\text { Rendah } \\
(<60)\end{array}$ & $\begin{array}{l}\text { Sedang } \\
(60-80)\end{array}$ & $\begin{array}{l}\text { Tinggi } \\
(>80)\end{array}$ & $\begin{array}{l}\text { Rataan } \\
\pm \text { Std }\end{array}$ & $\begin{array}{l}\text { Rendah } \\
(<60)\end{array}$ & $\begin{array}{l}\text { Sedang } \\
(60-80)\end{array}$ & $\begin{array}{l}\text { Tinggi } \\
(>80)\end{array}$ & $\begin{array}{c}\text { Rataan } \\
\pm \text { Std }\end{array}$ & \\
\hline & $\%$ & $\%$ & $\%$ & & $\%$ & $\%$ & $\%$ & & \\
\hline KF & 46 & 44 & 10 & $61,1 \pm 15,3$ & 46 & 42 & 12 & $63,3 \pm 15,5$ & 0,480 \\
\hline KP & 22 & 38 & 40 & $75,6 \pm 17,0$ & 14 & 40 & 46 & $79,3 \pm 15,6$ & 0,260 \\
\hline KS & 22 & 54 & 24 & $71,2 \pm 13,5$ & 22 & 40 & 38 & $75,3 \pm 15,4$ & 0,160 \\
\hline $\begin{array}{l}\text { Total } \\
\text { KSU }\end{array}$ & 26 & 56 & 18 & $68,9 \pm 12,9$ & 20 & 54 & 26 & $72,1 \pm 12,6$ & 0,210 \\
\hline
\end{tabular}

Tidak terdapat perbedaan yang signifikan pada variabel kualitas perkawinan antara dua kelompok baik pada indeks kualitas perkawinan total maupun per dimensi pada hasil uji beda (Tabel 4).

Marital Happiness. Hasil kajian menunjukkan bahwa marital happiness atau kebahagiaan perkawinan pada 66 persen pekerja sosial lama menikah $\leq 10$ tahun berada pada kategori sedang dan masing-masing 50 persen pekerja sosial lama menikah $>10$ tahun berada pada kategori sedang dan tinggi. $\mathrm{Hal}$ ini mengindikasikan bahwa pekerja sosial bahagia dengan perkawinannya.

Marita Satisfaction. Hasil kajian menunjukkan bahwa marital satisfaction atau kepuasan perkawinan pada 56 persen pekerja sosial lama menikah $\leq 10$ tahun dan 100 persen pekerja sosial lama menikah $>10$ tahun berada pada kategori tinggi. Hal ini mengindikasikan bahwa pekerja sosial merasa puas dengan perkawinannya.
Marital Adjustment. Hasil kajian menunjukkan bahwa marital adjustment atau penyesuaian perkawinan pada 60 persen pekerja sosial lama menikah $\leq 10$ tahun dan 66 persen pekerja sosial lama menikah $>10$ tahun berada pada kategori sedang. Hal ini mengindikasikan bahwa pekerja sosial cukup puas dengan penyesuaian perkawinannya.

\section{Pengaruh Karakteristik Pekerja Sosial dan Pasangan, Interaksi Suami-Istri, dan Kesejahteraan Subjektif terhadap Kualitas Perkawinan}

Hasil analisis uji pengaruh menemukan empat pengaruh langsung positif signifikan antar variabel penelitian dan satu pengaruh tidak langsung positif signifikan. Nilai R-Square pada hasil uji pengaruh menunjukkan nilai 0,546. Artinya, model penelitian ini menjelaskan sebesar 54,6 persen variabel penelitian memengaruhi kualitas perkawinan dan sisanya 45,4 persen dipengaruhi oleh variabel yang tidak dibahas dalam penelitian ini (Gambar 1).

Tabel 4 Sebaran pekerja sosial berdasarkan kategori indeks variabel kualitas perkawinan lama menikah

\begin{tabular}{|c|c|c|c|c|c|c|c|c|c|}
\hline \multirow{3}{*}{ Dimensi } & \multicolumn{4}{|c|}{ Lama Menikah $\leq 10$ th } & \multicolumn{4}{|c|}{ Lama Menikah >10 th } & \multirow{3}{*}{$\begin{array}{c}\mathrm{P}- \\
\text { value }\end{array}$} \\
\hline & $\begin{array}{l}\text { Rendah } \\
(<60)\end{array}$ & $\begin{array}{l}\text { Sedang } \\
(60-80)\end{array}$ & $\begin{array}{l}\text { Tinggi } \\
(>80)\end{array}$ & $\begin{array}{c}\text { Rataan } \\
\pm \text { Std }\end{array}$ & $\begin{array}{l}\text { Rendah } \\
(<60)\end{array}$ & $\begin{array}{l}\text { Sedang } \\
(60-80)\end{array}$ & $\begin{array}{l}\text { Tinggi } \\
(>80)\end{array}$ & $\begin{array}{c}\text { Rataan } \\
\pm S t d\end{array}$ & \\
\hline & $\%$ & $\%$ & $\%$ & & $\%$ & $\%$ & $\%$ & & \\
\hline$\overline{\mathrm{MH}}$ & 2 & 66 & 32 & $80,9 \pm 11,2$ & 0 & 50 & 50 & $82,2 \pm 11,3$ & 0,590 \\
\hline MS & 0 & 44 & 56 & $82,0 \pm 10,0$ & 0 & 0 & 100 & $84,6 \pm 10,3$ & 0,210 \\
\hline MA & 6 & 60 & 34 & $78,1 \pm 12,7$ & 4 & 66 & 30 & $76,5 \pm 12,3$ & 0,500 \\
\hline Total KPE & 2 & 44 & 54 & $81,5 \pm 9,5$ & 4 & 40 & 60 & $83,0 \pm 9,9$ & 0,420 \\
\hline
\end{tabular}

Keterangan: $\%=$ persentase sebaran pekerja sosial lama menikah $\leq 10$ tahun dan $>10$ tahun $(n=50),{ }^{* *}$ nyata pada $p \leq 0,01$;

*nyata pada $\mathrm{p} \leq 0,05 . \mathrm{KPE}=$ kualitas perkawinan, $\mathrm{MH}=$ marital happiness, $\mathrm{MS}=$ marital satisfaction, $\mathrm{MA}=$ marital adjustment. 


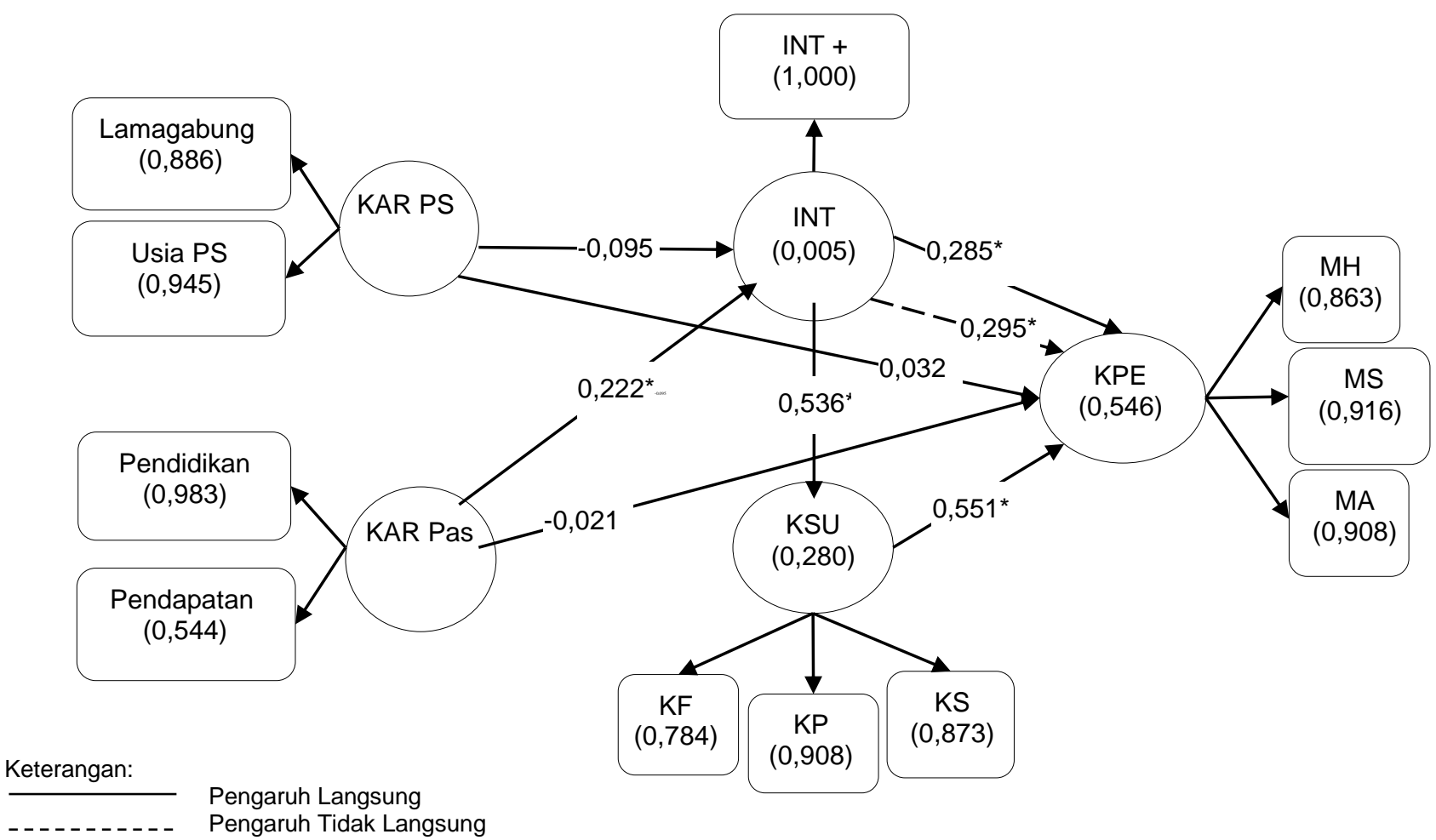

-_-_-_-_-_-_ Pengaruh Tidak Langsung

KAR PS=Karakteristik Pekerja Sosial; KAR Pas=Karakteristik Pasangan; INT+=Interaksi Suami-Istri; KSU=Kesejahteraan Subjektif; KF=Kesejahteraan fisik; KP=Kesejahteraan Psikologis; KS=Kesejahteraan Sosial; KPE= Kualitas Perkawinan; $\mathrm{MH}=$ Kebahagiaan Perkawinan; MS=Kepuasan Perkawinan; $\mathrm{MA}=$ Penyesuaian Perkawinan; *) antar variabel berpengaruh positif signifikan.

Gambar 1 Model SEM pengaruh karakteristik pekerja sosial, karakteristik pasangan, interaksi suami istri, kesejahteraan subjektif terhadap kualitas perkawinan

Karakteristik pasangan yang terdiri atas pendapatan dan pendidikan $(\beta=0,222 ; t>1,96)$ berpengaruh langsung positif signifikan terhadap interaksi suami-istri.

Tabel 5 Pengaruh langsung, tidak langsung, dan total antar variabel penelitian

\begin{tabular}{|c|c|c|c|}
\hline Variabel & TE & $\mathrm{DE}$ & TIE \\
\hline \multicolumn{4}{|l|}{$\begin{array}{l}\text { Karakteristik pekerja } \\
\text { sosial }\end{array}$} \\
\hline Interaksi suami-istri & $-0,095$ & $-0,095$ & \\
\hline $\begin{array}{l}\text { Kesejahteraan } \\
\text { subjektif }\end{array}$ & 0,058 & & $-0,051$ \\
\hline Kualitas perkawinan & 0,037 & 0,032 & 0,005 \\
\hline \multicolumn{4}{|l|}{ Karakteristik pasangan } \\
\hline Interaksi suami-istri & $0,222^{*}$ & $0,222^{*}$ & \\
\hline $\begin{array}{l}\text { Kesejahteraan } \\
\text { subjektif }\end{array}$ & 0,071 & & 0,119 \\
\hline Kualitas perkawinan & 0,081 & $-0,021$ & 0,103 \\
\hline \multicolumn{4}{|l|}{ Interaksi suami-istri } \\
\hline $\begin{array}{l}\text { Kesejahteraan } \\
\text { subjektif }\end{array}$ & $0,536^{*}$ & $0,536^{*}$ & \\
\hline Kualitas perkawinan & 0,580 * & $0,285^{*}$ & $0,295^{*}$ \\
\hline \multicolumn{4}{|l|}{ Kesejahteraan subjektif } \\
\hline Kualitas perkawinan & $0,551^{*}$ & $0,551^{*}$ & \\
\hline
\end{tabular}

Keterangan: *signifikansi pada $\mathrm{t}>1,96$; DE: Direct Effect (pengaruh langsung), IE: Total Indirect Effect (total pengaruh tidak langsung), TE: Total Effect (pengaruh total)
Sementara itu, interaksi suami-istri $(\beta=0,536$; $t>1,96$ ) memiliki pengaruh langsung positif signifikan terhadap kesejahteraan subjektif. Interaksi suami-istri $(\beta=0,285 ; t>1,96)$ juga memiliki pengaruh langsung positif signifikan terhadap kualitas perkawinan. Kemudian, kesejahteraan subjektif $\quad(\beta=0,551 ; \quad t>1,96)$ memiliki pengaruh langsung positif signifikan terhadap kualitas perkawinan. Kesimpulannya, variabel interaksi suami-istri dan kesejahteraan subjektif memiliki pengaruh langsung positif signifikan terhadap kualitas perkawinan.

Pengaruh tidak langsung positif signifikan ditemukan pada interaksi suami-istri $(\beta=0,295$; $t>1,96)$ dan kualitas perkawinan melalui kesejahteraan subjektif. Pengaruh tidak langsung menunjukkan bahwa pengaruh interaksi suami-istri terhadap kualitas perkawinan dijelaskan oleh kesejahteraan subjektif. Dekomposisi efek pada penelitian dapat dilihat pada Tabel 5.

\section{PEMBAHASAN}

Karakteristik pasangan yang terdiri atas indikator pendidikan dan pendapatan berpengaruh positif signifikan terhadap interaksi 
suami-istri. Seperti penelitian yang dilakukan oleh Chan dan Elder (2001), status pendidikan dan ekonomi berpengaruh terhadap kondisi dan interaksi keluarga. Adams dan Butler (1967) juga menjelaskan bahwa derajat pengetahuan pasangan berpengaruh terhadap pola interaksi suami-istri. Begitupun penelitian Marzuki (2019) yang menunjukkan bahwa kemampuan kepala rumah tangga dalam mencukupi kebutuhan ekonomi berpengaruh terhadap hubungan suami-istri.

Interaksi suami-istri dan kesejahteraan subjektif berpengaruh langsung positif signifikan terhadap kualitas perkawinan. Hasil penelitian ini selaras dengan penelitian yang dilakukan oleh Dewi et al. (2019) yang menemukan bahwa semakin tinggi interaksi suami-istri, maka tinggi pula kualitas perkawinan pasangan. Haring-Hidore et al. (1985) juga mengindikasikan bahwa perkawinan sangat berasosiasi positif dan signifikan dengan kesejahteraan subjektif. Carr et al. (2014) mengungkapkan bahwa terdapat asosiasi antara kebahagiaan perkawinan dengan kualitas perkawinan. Nilai R-Square pada hasil uji pengaruh model interaksi suami-istri dan kesejahteraan subjektif terhadap kualitas perkawinan menunjukkan nilai moderat yaitu 0,546 . Hal tersebut menjelaskan model dapat menjelaskan secara moderat variabel-variabel yang memengaruhi kualitas perkawinan dan sisanya dipengaruhi oleh variabel lain, seperti modal sosial (Dewi et al., 2019) dan relasi gender (Schulz et al., 2004) yang tidak dibahas dalam penelitian.

Pada variabel interaksi suami-istri, terdapat tiga dimensi yang skornya perlu ditingkatkan yaitu directing, note domineering, dan note submissive. Directing adalah sikap dalam mengarahkan pasangan untuk melakukan sesuatu yang baik. Note domineering adalah dominasi yang dilakukan pasangan dengan cara yang melibatkan emosi untuk mendapatkan tujuan tertentu. Note submissive adalah sikap saling menuruti keinginan atau harapan dari pasangan. Merujuk pada Carson (1969) dan Kiesler (2983) dalam Chuang (2005), hubungan yang komplementer atau yang saling melengkapi terjadi ketika terdapat timbal balik dengan penuh rasa hormat terhadap dimensi yang memerlukan kontrol diri, dalam penelitian ini seperti dimensi directing, note domineering, dan note submissive.

Pada variabel kesejahteraan subjektif, semua dimensi yang terdiri atas kesejahteraan fisik, kesejahteraan psikologis, dan kesejahteraan sosial berada pada kategori sedang sehingga masih perlu ditingkatkan. Namun, nilai rata-rata indeks kesejahteraan fisik paling rendah di antara ketiga dimensi tersebut. Niedzwiedz et al. (2016) menyatakan bahwa tingkat keterlibatan individu di kegiatan sosial berasosiasi dengan rendahnya risiko serta perasaan sendirian dan berasosiasi dengan kesehatan rumah tangga. Wilson (2004) menyatakan bahwa individu yang bekerja pada organisasi sosial memiliki dampak terhadap kesehatan dan kesejaheraan kehidupannya. Littlepage, Obergfell, dan Zanin (2003) serta Zhang dan Zhang (2015) menunjukkan bahwa kekerabatan dan keakraban keluarga semakin tinggi jika keluarga tersebut melakukan partisipasi atau kegiatan sosial. Morrow-Howell et al. (2003) juga menjelaskan bahwa bertambah usia dan semakin banyaknya keterlibatan dalam kegiatan sosial akan meningkatkan kesehatan fisiknya. Keaktifan pekerja sosial pada kegiatan-kegiatan positif di PKK perlu ditingkatkan agar kesejahteraan fisik, kesejahteraan psikologis, dan kesejahteraan sosialnya dapat meningkat.

Sementara itu, ditemukan pula pengaruh tidak langsung interaksi suami-istri terhadap kualitas perkawinan melalui kesejahteraan subjektif secara signifikan dengan nilai koefisien beta sebesar 0,295. Hasil ini bermakna bahwa mendapatkan kualitas perkawinan yang baik bukanlah hal yang mudah dan diperlukan upaya untuk meraihnya. Salah satunya adalah dengan merasa puas dan merasa sejahtera dengan kehidupan diri dan keluarga yang sedang dijalani. Penjabaran hasil penelitian di atas sejalan dengan penelitian Iskandar (2012) yang mengungkapkan bahwa interaksi perkawinan menjadi salah satu yang memengaruhi kesejahteraan rumah tangga.

Yousefi et al. (2009) juga menunjukkan bahwa ketergantungan suami dan istri adalah faktor penting dari kesejahteraan subjektif individu seperti kesejahteraan psikologis dan rasa bahagia seseorang. Kualitas perkawinan sendiri digunakan untuk memberikan penjelasan mengenai persepsi subjektif individu terhadap kepuasan dan kebahagiaan perkawinannya (Adamczyk \& Segrin, 2015). Yuliana dan Valentina (2016) juga menyatakan bahwa cara pasangan berinteraksi dan menyelesaikan masalah akan menentukan kepuasan perkawinannya.

Hasil uji beda pada variabel karakteristik pekerja sosial dan pasangan, interaksi suamiistri, kesejahteraan subjektif, dan kualitas perkawinan tidak menampakkan adanya perbedaan yang signifikan antara dua kelompok pekerja sosial berdasarkan lama 
menikah. Sebuah perkawinan cenderung mengalami penurunan kualitas secara bertahap dimulai dari tahun pertama perkawinan, kemudian 0-5 tahun, 10 tahun, dan 15 tahun (Carrere et al., 2000). Pernyataan ini tidak terbukti pada pekerja sosial sebagai subjek penelitian.

Penelitian yang dilakukan oleh Hansen et al. (2018) menemukan bahwa loyalitas bergabung di organisasi sosial dapat membawa keuntungan untuk individu seperti kesehatan, dukungan sosial, dan percaya diri. Pernyataan tersebut didukung oleh hasil penelitian bahwa mayoritas pekerja sosial pada kelompok lama menikah kurang dari 10 tahun tergolong dewasa awal (20-40 tahun) dan telah bergabung di PKK selama 1,58 tahun, sedangkan pekerja sosial pada kelompok lama menikah lebih dari 10 tahun tergolong dewasa madya (40-60 tahun) dan telah bergabung di PKK selama 9,52 tahun. Hasil penelitian menunjukkan bahwa pekerja sosial lama menikah >10 tahun memiliki kesejahteraan subjektif yang lebih baik dibandingkan pekerja sosial lama menikah $\leq 10$ tahun. Profesi yang banyak digeluti oleh para pekerja sosial adalah ibu rumah tangga. Hal tersebut sejalan dengan temuan penelitian Kartikasari et al. (2019) yang menyebutkan bahwa ibu rumah tangga lebih banyak mengikuti kegiatan kerelawanan seperti menjadi kader.

Rata-rata pendapatan keluarga per bulan kedua kelompok pekerja sosial berdasarkan lama menikah tergolong sangat tinggi yaitu kelompok lama menikah $\leq 10$ tahun adalah Rp8.772.333 dan rata-rata pendapatan per tahun kelompok lama menikah $>10$ tahun adalah Rp6.048.363. Pendapatan tersebut berada di atas Rp6.000.000 per bulan yang terkategori keluarga berpendapatan tinggi (BPS, 2019). Temuan tersebut sejalan dengan penelitian Lee (2019) yang menyatakan bahwa melakukan hal sosial berasosiasi dengan pendapatan yang berarti orang cenderung bahagia dan menjadi relawan jika puas dengan pendapatannya. Data yang diungkapkan sejalan dengan penelitian yang dilakukan oleh Kusminah (2018), tugas PKK adalah menjadi role model untuk menyebarkan informasi kepada masyarakat di sekitarnya termasuk di dalamnya adalah informasi tentang pemberdayaan dan kesejahteraan keluarga.

Data penelitian menunjukkan bahwa hanya interaksi suami-istri yang terkategori tinggi, yaitu 80,4 persen untuk kelompok pekerja sosial lama menikah $\leq 10$ tahun dan 80,6 persen untuk kelompok pekerja sosial lama menikah >10 tahun. Artinya, pekerja sosial memiliki pola interaksi dan komunikasi yang baik dengan pasangannya. Sementara itu, kesejahteraan subjektif masih berada pada kategori sedang yang berarti pekerja sosial merasa cukup puas dengan perkawinannya dengan pasangan. Lebih lanjut, kedua variabel tersebut harus ditingkatkan lagi agar pekerja sosial dapat memenuhi syarat yang baik sebagai role model atau panutan dalam hal pemberdayaan dan kesejahteraan keluarga.

Hasil pada penelitian ini tidak sejalan dengan penelitian yang telah dilakukan oleh Carrere et al. (2000) yang menjelaskan bahwa kualitas perkawinan akan turun seiring dengan bertambahnya usia perkawinan. Penelitian ini hanya meneliti pekerja sosial yang berprofesi sama yaitu pengurus PKK di DKI Jakarta sehingga tidak dapat dilakukan uji beda untuk memahami pengaruh antar variabel pada kelompok pekerja sosial lainnya.

\section{SIMPULAN DAN SARAN}

Berdasarkan temuan penelitian, tidak ada perbedaan signifikan antara kedua kelompok pekerja sosial berdasarkan usia pernikahan. Pada uji pengaruh ditemukan bahwa faktor yang memengaruhi secara langsung positif signifikan variabel kualitas perkawinan adalah interaksi suami-istri dan kesejahteraan subjektif. Artinya, semakin tinggi interaksi suami-istri dan kesejahteraan subjektif, maka semakin tinggi kualitas perkawinan pekerja sosial. Karakteristik pasangan yang terdiri atas pendidikan dan pendapatan juga berpengaruh positif signifikan terhadap interaksi suami-istri. Artinya, semakin tinggi pendidikan dan pendapatan pasangan, maka interaksi suamiistri menjadi semakin baik. Sementara itu, pengaruh tidak langsung positif signifikan ditemukan antara variabel interaksi suami-istri dan kualitas perkawinan melalui variabel kesejahteraan subjektif. Artinya, perlu upaya sadar untuk meningkatkan interaksi suami-istri dan kesejahteraan subjektif untuk mendapatkan kualitas perkawinan yang baik. Interaksi suamiistri sangat menentukan kualitas perkawinan. Maka dari itu, pekerja sosial perlu lebih terbuka dalam menyampaikan saran untuk pasangan, lebih bersikap lemah lembut, dan terbuka ketika menerima masukan dari pasangan. Pada dasarnya, pekerja sosial bisa berkarir di luar rumah namun dengan tetap meningkatkan interaksi suami-istri dan kesejahteraan subjektif dirinya. Pekerja sosial PKK kelurahan juga berpotensi untuk bisa menjadi mitra strategis 
pemerintah khususnya untuk program-program yang berkaitan dengan peningkatan kualitas perkawinan.

Penelitian ini diharapkan memberikan manfaat bagi pemerintah dalam membuat kebijakan untuk pekerja sosial, memberikan pertimbangan bagi PKK untuk menentukan tugas pokok dan fungsi ideal bagi pengurusnya, serta memberikan pemahaman bagi masyarakat terkait pengaruh interaksi suamiistri dan kesejahteraan subjektif terhadap kualitas sebuah perkawinan. PKK disarankan untuk mempertimbangkan keterlibatan pasangan pekerja sosial dalam kegiatan yang dijalankan agar kondisi internal dan hubungan perkawinan pekerja sosial menjadi semakin kuat. Keterbatasan penelitian ini adalah hanya melihat interaksi suami-istri dari perspektif istri. Untuk itu, penelitian selanjutnya disarankan untuk melibatkan perspektif pasangan pekerja sosial agar lebih dapat melihat hubungan dua arah. Selain itu, penelitian ini hanya meneliti pekerja sosial pada jenis pekerjaan yang sama yaitu Pengurus PKK di Provinsi DKI Jakarta. Penelitian selanjutnya diharapkan dapat mengambil subjek penelitian yang berbeda yaitu pekerja sosial selain PKK untuk bisa menguji perbedaan kualitas perkawinan yang signifikan. Pengaruh kegiatan-kegiatan PKK yang dilakukan terhadap kualitas perkawinan atau kesejahteraan keluarga pekerja sosial juga dapat dipertimbangkan untuk dianalisis selanjutnya.

\section{DAFTAR PUSTAKA}

Adams, B. N., \& Butler, J. E. (1967). Occupational status and husband-wife social participation. Social Forces, 45(4), 501-507. doi:10.1093/sf/45.4.501.

Adamczyk, K., \& Segrin, C. (2015). Perceived social support and mental health among single vs. partnered Polish young adults. Current Psychology, 34(1), 82-96. doi:10.1007/s12144-014-9242-5.

Anderson, S., \& Sabatelli, R. (2011). Family Interaction. United States of America, US: Pearson Education.

Anderson, W. A. (1943). The family and individual social participation. American Sociological Review, 8(4), 420-424. doi:10.2307/2085803.

Anindya, A. S., \& Soetjiningsih, C. H. (2017). Kepuasan perkawinan dengan kesejahteraan subjektif perempuan dengan profesi guru sekolah dasar. INSAN Jurnal Psikologi dan Kesehatan
Mental, 2(1), 44-50. doi:10.20473/jpkm.V2I12017.44-50.

[ATR/BPN] Agraria dan Tata Ruang/Kepala Badan Pertanahan Nasional. (2019). Total Luas Perkampungan Kumuh Hampir Separuh Luas DKI. [Internet]. Retrieved from https://jakarta.bisnis.com/read/20190527/7 7/927975/total-luas-perkampungankumuh-hampir-separuh-luas-dki.

[BPS] Badan Pusat Statistik. (2019). Berita Resmi Statistik: Tingkat Kemiskinan dan Ketimpangan di DKI Jakarta (Maret 2019) [Internet]. Retrieved from https://jakarta.bps.go.id/pressrelease/2019 /01/15/332/tingkat-kemiskinan-danketimpangan-2018--di-dki-jakarta-.html.

Bradbury, T. N., Fincham, F. D., \& Beach, S. R. (2000). Research on the nature and determinants of marital satisfaction: A decade in review. Journal of Marriage and Family, 62(4), 964-980. doi:10.1111/j.1741-3737.2000.00964.X.

Canel, A. N. (2013). The development of the marital satisfaction scale (MSS). Educational Sciences: Theory and Practice, 13(1), 97-117.

Carr, D., Freedman, V. A., Cornman, J. C., \& Schwarz, N. (2014). Happy marriage, happy life? Marital quality and subjective well-being in later life. Journal of Marriage and Family, 76(5), 930-948.

Carrere, S., Buehlman, K. T., Gottman, J. M., Coan, J. A., \& Ruckstuhl, L. (2000). Predicting marital stability and divorce in Newlywed Couples. Journal of Family Psychology, 14(1), 42-58. doi:10.1037/0893-3200.14.1.42.

Chan, C. G., \& Elder Jr, G. H. (2001). Family influences on the social participation of youth: The effects of parental social involvement and farming. Rural sociology, $66(1)$ 22-42. doi:10.1111/j.15490831.2001.tb00053.x.

Chuang, Y. C. (2005). Effects of interaction pattern on family harmony and well-being: Test of interpersonal theory, relational-models theory, and confucian ethics. Asian Journal of Social Psychology, $8(3), \quad 272-291 . \quad$ doi:10.1111/j.1467839X.2005.00174.x.

DeVellis, R. F., Lewis, M. A., \& Sterba, K. R. (2003). Interpersonal emotional processes in adjustment to chronic illness. Social Psychological Foundations of Health and 
Illness, 1(1), 256-287. doi:10.1002/9780470753552.ch10.

Dewi, E. M., Puspitawati, H., \& Krisnatuti, D. (2019). the effect of social capital and husband-wife interaction on marital quality among familiesin early years and middle years marriage. Journal of Family Sciences, 30 30-40. doi:10.29244/jfs.3.1.30-40.

Hansen, T., Aartsen, M., Slagsvold, B., \& Deindl, C. (2018). Dynamics of volunteering and life satisfaction in midlife and old age: Findings from 12 European countries. Social Sciences, 7(5), 78. doi:10.3390/socsci7050078.

Haring-Hidore, M., Stock, W. A., Okun, M. A., \& Witter, R. A. (1985). Marital status and subjective well-being: A research synthesis. Journal of Marriage and the Family, 47(4), 947-953. doi:10.2307/352338.

Iskandar, A. (2012). Kebijakan dan implementasi pemberdayaan masyarakat melalui pabrik garam. Jurnal Sosial Humaniora, 3(1), 9-21. doi:10.30997/jsh.v3i1.351.

Kartikasari, A., Anggraeni, M. D., Latifah, L., \& Setiawati, N. (2019). The community health volunteers description in exclusive breastfeeding promotion and improved knowledge through training based on the concept of "Insufficient Milk Supply". In IOP Conference Series: Earth and Environmental Science: IOP Publishing, 255(1), 012-026.

Komariah, N., Prijana, P., \& Winoto, Y. (2018). Upaya pemberdayaan perempuan melalui pelatihan literasi informasi kesehatan pada ibu-ibu kader PKK di Kecamatan Jatinangor Kabupaten Sumedang. Dharmakarya, 7(1), 26-31.

Kusminah, I. L. (2018). Penyuluhan 4r (Reduce, Reuse, Recycle, Replace) dan kegunaan bank sampah sebagai langkah menciptakan lingkungan yang bersih dan ekonomis di Desa Mojowuku Kab. Gresik. JPM17: Jurnal Pengabdian Masyarakat, 3(01), 22-28. doi:10.30996/jpm17.v3i01.1165.g1003.

Lee, M. A. (2019). Volunteering and happiness: Examining the differential effects of volunteering types according to household income. Journal of Happiness Studies, 20(3), 795-814.
Littlepage, L., Obergfell, E., \& Zanin, G. (2003). Family Volunteering: An Exploratory Study of the Impact On Families. Indianapolis, IN: Purdue University Indianapolis.

Marzuki, S. N. (2019). Relevansi kesejahteraan ekonomi keluarga dengan peningkatan perceraian di Kabupaten Bone. Al-Risalah: Jurnal Hukum Keluarga Islam (Ahwal AlSyakhsiyah), 2(2).

Megapolitan.antaranews.com. (2017). Harapan Presiden Jokowi Kepada Para Kader PKK. Retrieved from https://megapolitan.antaranews.com/berita /33043/harapan-presiden-jokowi-kepadapara-kader-pkk.

Morrow-Howell, N., Hinterlong, J., Rozario, P. A., \& Tang, F. (2003). Effects of volunteering on the well-being of older adults. The Journals of Gerontology Series $B$ : Psychological Sciences and Social Sciences, 58(3), $\quad$ S137-S145. doi:10.1093/geronb/58.3.S137.

Niedzwiedz, C. L., Richardson, E. A., Tunstall, H., Shortt, N. K., Mitchell, R. J., \& Pearce, J. R. (2016). The relationship between wealth and loneliness among older people across Europe: Is social participation protective? Preventive Medicine, 91(1), 2431. doi:10.1016/j.ypmed.2016.07.016.

Riyanti, D., Prabowo, H., \& Puspitawati, I. (1998). Psikologi Umum 2. Jakarta, ID: Universitas Gunadarma.

Schulz, M. S., Cowan, P. A., Pape-Cowan, C., \& Brennan, R. T. (2004). Coming home upset: Gender, marital satisfaction, and the daily spillover of workday experience into couple interactions. Journal of Family Psychology, 18(1), 250. doi:10.1037/08933200.18.1.250.

Syam, N. K., Nandang, H. M. Z., Al Farisi, S., \& Day, J. I. (2015). Pelatihan parenting: Komunikasi pengasuhan anak usia dini bagi orang tua, pendidik dan Kader PKK di Desa Nagrog Cicalengka. Prosiding SNaPP: Sosial, Ekonomi dan Humaniora, $5(1)$, 165-172. doi:10.1177/0265407510382061.

Umberson, D., Williams, K., Powers, D. A., Liu, H., \& Needham, B. (2006). You make me sick: Marital quality and health over the life course. Journal of Health and Social Behavior, 47(1), 1-16. doi:10.1177/002214650604700101. 
Wanyama, J. B. (2017). Exploring the influence of family structure on self-esteem and attitude toward violent crime among youth (Doctoral dissertation). Nairobi, KE: University of Nairobi.

Williams, K. (2003). Has the future of marriage arrived? A contemporary examination of gender, marriage, and psychological wellbeing. Journal of Health and Social Behavior, 44(4), 470-487. doi:10.2307/1519794.

Wilson, M. G., Dejoy, D. M., Vandenberg, R. J., Richardson, H. A., \& Mcgrath, A. L. (2004). Work characteristics and employee health and well-being: Test of a model of healthy work organization. Journal of Occupational and Organizational Psychology, 77(4), 565-588. doi:10.1348/0963179042596522.

Yousefi, N., Etemadi, O., Bahrami, F., Fatehzadeh, M., Ahmadi, S. A., \&
Beshlideh, K. (2009). Structural relationships between self-differentiation and subjective wellbeing, mental health and marital quality. Iranian Journal of Psychiatry and Behavioral Sciences (IJPBS), 3(2), 4-14. Retrieved from https://www.sid.ir/en/journal/ViewPaper.as px?id=166327.

Yuliana, I. A. I., \& Valentina, T. D. (2016). Dyadic coping dan kepuasan pernikahan pasangan suami 1 istri dengan suami diabetes melitus tipe ii. Jurnal Psikologi Udayana, 3(2), 324-331. doi:10.24843/JPU.2016.v03.i02.p14.

Zhang, Z., \& Zhang, J. (2015). Social participation and subjective well-being among retirees in China. Social Indicators Research, 123(1), 143-160. 